

\title{
DOES FINANCIAL DEVELOPMENT PROMOTES INNOVATION IN DEVELOPING ECONOMIES? An Empirical Analysis
}

\author{
Maria Aristizabal-Ramirez \\ Universidad EAFIT, \\ Medellin Colombia
}

\author{
Maria Botero-Franco \\ Universidad EAFIT, \\ Medellin Colombia
}

\author{
Gustavo Canavire-Bacarreza \\ Universidad EAFIT, \\ Medellin Colombia
}

\section{January 2015}

\begin{abstract}
Using firm-level data from 2006 to 2013 for a set of developing countries, we examine the effects of financial development on innovation. Financial development boosts innovation by improving resource allocation and investment toward strategic sectors as well as facilitating technology to promote growth. Using binary response models as well as instrumental variable techniques to correct for endogeneity, we find robust but puzzling results. Contrary to most existing literature, financial development has a negative effect on the probability of a firm to innovate. The effect is conditional on firm size, and only larger firms are the ones that benefit from financial development. These results are robust to different measures of financial development. We argue that this is a result of the design of the financial system in regards to the lack of capital and the institutional system. Consequently, developing countries should first generate appropiate insitutional conditions if they want financial development to spur growth through innovation.
\end{abstract}

JEL codes: G00, G23, 031, 029

Keywords: Financial Development, Innovation, Economic Growth, Developing Countries 


\section{Introduction}

Financial development boosts economic growth by lowering information and transaction costs when mobilizing resources (Levine, 2005). However, the existing literature shows ambiguous results in this relationship. On the one hand, based on theoretical and empirical work, Levine (2005) argues that financial development has a positive effect on growth by improving resource allocation. On the other hand, Rousseau and Wachtel (2011) suggest the benefits of financial deepening could lead many countries to liberalize before developing legal and regulatory institutions, and that could attenuate the positive effect of financial development on economic growth. Moreover, Blanco (2013), using a sample of Latin American countries, finds that financial development has no significant effect on economic growth in the short term, but there are long-term differentiated effects.

Two related reasons may explain why understanding the relationship between financial development and economic growth is difficult. First, the channels through which financial development operate are not well understood. Second, current studies do not differentiate the effect of financial development on growth at different stages of economic development (Levine(1997), Levine (2005), Blanco (2013))ํ․ This paper tackles the first reason by providing significant evidence on the effects of financial development on innovation in developing countries.

From a classical perspective, following Schumpeter's (1911) thinking, financial intermediaries facilitate technological innovation and then affect growth and development. Moreover, as suggested by Levine (2005), financial development improves resource allocation by creating innovative processes that promote investment, and that simultaneously leads to greater productivity and then to economic growth.

Highly developed countries with innovative processes achieve economic growth and capital accumulation through global innovation networks that include institutions such as universities and think tanks, the production sector, global trade networks consisting of domestic and foreign markets, public policy makers, and financial channels (Moguillansky, 2006). Therefore, the effects of financial development on innovation are expected to be positive, but developing countries have limited access to global innovation networks due to a limited number of universities and limited (or nonexistent) interaction between different institutions. Along with a limited financial sector, this may reduce the effects of financial development on innovation.

\footnotetext{
${ }^{1}$ According to the literature review on economic growth and financial development, the ambiguity of the effect might rely on the stage of development. That is, the effect is not the same for developed economies as it is for developing economies.
} 
To examine the relationship between financial development and innovation in developing economies, we use binary response models, particularly probit models. Following Benfratello et al. (2008), the dependent variable is the probability of a firm to innovate, but we do not differentiate the effects of financial development on product innovation and process innovation because those are out of the scope of this paper. More specifically, in order to measure the effects on innovation as a whole, we use the probability of a firm to introduce new products, processes, or patents to the market as our dependent variable.

Given that there is a potential endogenous relationship between financial development and innovation due to reverse causality and omitted variable bias, we apply instrumental variable techniques. We include legal origins as an instrument for financial development. La Porta et al. (1997, 1998) show that a country's legal origin (English, French, German, or Scandinavian system) defines the current legal rules regarding the protection of corporate shareholders and creditors and influences the size of the debt and equity markets. Thus, it satisfies the condition of relevance of legal origins as an instrument. Furthermore, as suggested by Rajan and Zingales (1998) and Beck and Levine (2002), most countries acquired their legal systems through occupation and colonialism; therefore, the legal origin of a country can be regarded as exogenous and is likely to satisfy the exclusion restriction of instrumental variables.

In the structure of the paper, we present the literature review in the next section. In the third section, we briefly define financial development and innovation concepts and show the descriptive statistics. In the fourth section, we specify the empirical model. In the fifth section, we interpret the results, and in the final section, we provide our conclusions.

\section{Where Do We Stand? A Brief Review of the Existing Literature}

Although existing theory (Tadesse,2005; Sylla et al.,2006; Dabla-Norris et al.,2012; Brown et al. 2012; among others ) asserts that increases in financial development push for larger and newer technological processes as well as better allocation of resources and investments toward innovation, the empirical evidence is not yet conclusive. This is mainly because financial development spurs innovation conditional in different factors, such as the size of the economy, the type of industries, and its institutions (Sylla et al., 2006).

From a more theoretical perspective, Dabla-Norris et al. (2012) examine the effects of financial development on innovation and productivity and argue that the relationship between financial development, innovation, and productivity relies on the capability of the financial system to optimally allocate capital. That is, "In a country with a well-developed financial sector, good innovation projects are more likely to be funded than bad ones" (Dabla-Norris et al., 2012). These authors also suggest the effects of financial development are greater for high technology 
firms than for low technology firms. Similarly, Tadesse (2005) finds evidence that industries in financially well-developed countries significantly reduce real costs that are later transformed in innovation. He argues that greater financial development in a country leads to more productivity through innovation. This is because the adoption of new technologies requires high amounts of physical capital, which is dependent on well-developed capital markets and institutions encouraging long-term investments through the reduction of liquidity risks. In this vein, Brown et al. (2012) argue that R\&D is susceptible to financing constraints for several reasons. Besides the lack of collateral value and asymmetric information problems, R\&D may face adverse selection and moral hazard problems, especially for younger, smaller firms. For those firms, financial constraints may drive investment in R\&D well below the privately optimal level in a world with no financial frictions. They find that access to equity finance is relevant to R\&D because public stock markets can foster economic growth by directly funding the innovative activity of young, entrepreneurial firms. Although they show that the absence of financing constraints increases innovative activity, they did not clearly answer the question of what effect financial development has on innovation.

Perhaps closer papers to ours are those containing the empirical approaches used by Hsu et al. (2014) and Sharma (2007). The first one evaluates the relationship between financial development and innovation using cross country evidence, and it finds that equity markets encourage innovation in high-tech industries and in industries that are highly dependent on external finance, in opposition to credit markets that discourage it. They highlight that these effects are more pronounced in emerging countries and that such effects are strengthened or weakened according to the level of legality and the shareholders' protection. Similarly, Sharma (2007) emphasizes that the relationship between financial development and innovation is conditional on the firm size and argues that financial development does not equally affect firms of different sizes. This author, who studies the problem through micro-data, finds that the probability of small firms to invest in $R \& D$ as a proxy for innovation is higher if a country is financially well developed. The author argues that this relationship can have positive redistributive consequences in terms of encouraging small firms to invest in R\&D. However, Sharma (2007) does not take into account the endogenous relationship of the variables, which may bias the coefficient estimates and make interpretation of his results difficult. He also omits controls such as the variables related to the environment where firms operate, which are factors that facilitate the way to achieve innovation, according to Camagni (1995) and Moguillansky (2006). 


\section{III.Definitions and Data}

To examine the relationship between financial development and innovation, we use the firmlevel dataset from the World Enterprise Surveys (World Bank Group, 2013) that were conducted between 2006 and 2013. This dataset is pooled to provide more information for the analysis. In order to account for macro and institutional factors, we complement the dataset with country-level data. The main source for the country-level data is the World Development Indicators (The World Bank, 2013).

Considering that innovation is a concept that encompasses different aspects that range from the process of firm decision making to legal systems, measuring it is not an easy task, and its discussion has been widely presented in the literature (Bhattacharya and Bloch, 2004; DablaNorris et al., 2012; Sharma, 2007; among others). We use a comprehensive concept that encompasses the creation or development of a new product or service, a new process, or the existence of patents. Therefore, we define innovation in a dichotomous way, where 0 means the company does not have patents or new products, services, or processes, and 1 means it presents any of the three types. Financial development is measured as the ratio of private credit to GDP. Following Beck et al. (2007), we argue that this is the best measure for financial development because it "captures the amount of credit channeled from savers, through financial intermediaries, to private firms." Moreover, we recognize the existence of an endogenous relationship between financial development and innovation. On the one hand, financial development can lead to innovative processes, but on the other hand, one could say that more innovation can cause more financial development in terms of an increasing demand for funding (Benfratello et al., 2008). To solve this problem, we are using the instrumental variable suggested by La Porta et al. (1998, 1997) and then used by several authors like Levine et al. (2000) Levine (2005) and Clarke et al. (2006). This variable consists of linking financial development with the legal origin of the country from The Foreign Law Guide (Marci Hoffman, 2014). La Porta et al.'s main idea is that because it is not arranged by the country, the legal system represents the capacity of the system to protect property rights and adapt itself to the newer circumstances. In that order of ideas, La Porta et al., based on Reynolds' and Flores' classification, identifies four types of legal origins: common law or English, French, German, and Scandinavian, with the last three coming from Roman civil law traditions. La Porta et al.'s findings indicate that common law is associated with higher financial development due to the use of jurisprudence as the main source of obligations. In addition, a set of controls used in previous literature are included in order to account for factors such as the size of the economy and wealth, human capital, firm size, and industry.

Our dataset consists of 15,215 representative firms from 24 emerging countries (see Appendix 1) mostly located in Latin America and the Caribbean (77.7\%), followed by Asia 
(15.3\%), and Africa (7\%). In terms of sector industry, it consists of data from 13 different industries, with the largest share of firms operating in the food industry (22.46\%), and the remainder consisting of other manufacturing (16.71\%), garments (14.41\%), and chemicals and pharmacy (13.03\%) (see Appendix 1). Regarding our innovation definition, $61 \%$ of the companies answered that they do not have innovation processes, and the remaining $39 \%$ have at least one innovative process, product, or patent ${ }^{2}$. Furthermore, $63 \%$ of the firms innovate through new products or services, $60 \%$ through new processes, and only $11 \%$ have patents. In addition, the survey provides the value of total sales (in U.S. million dollars) as well as the number of employees. Those are the measures of firm size we use in the estimations of the model. The largest firm in the sample reported $\$ 500$ million in annual sales, while the smallest reported $\$ 2,300$. The average of annual sales ( $\$ 75.5$ million) and its standard deviation $(\$ 5.05$ million) creates large size differences in the sample. In terms of employees, the survey classifies the firm size in three groups based on the number of employees. Small firms have fewer than 20 employees and represent $41 \%$ of the sample. Medium firms have between 20 and 99 employees and represent $36 \%$ of the sample, and large firms have more than 100 employees and represent $23 \%$ of the sample. It is also essential to note that small firms are given a value of 1 , medium firms a value of 2 , and large firms a value of 3 .

The survey asks several questions related to the institutional system perception. We consider the question, "What percentage of senior management time was spent in dealing with government regulations?" The answers give us an idea of the institutional environments in which the firms operate. According to the data, 256 firms answered that the percentage of time senior management spent dealing with government regulations was $100 \%$, while 3,506 firms answered that it was $0 \%$. The average was $13.6 \%$ of their time.

Table 1 Descriptive Statistics

\begin{tabular}{|l|c|c|c|c|c|c|}
\hline \multicolumn{1}{|c|}{ Variable } & Source & Obs & Mean & $\begin{array}{l}\text { Std. } \\
\text { Dev. }\end{array}$ & $\begin{array}{c}\text { Minimu } \\
\text { m }\end{array}$ & $\begin{array}{c}\text { Maximu } \\
\text { m }\end{array}$ \\
\hline Innovation Index & WES & 15215 & 0.616 & 0.835 & 0 & 2 \\
\hline Innovation Dummy & WES & 15215 & 0.386 & 0.487 & 0 & 1 \\
\hline $\begin{array}{l}\text { Product or service } \\
\text { innovation }\end{array}$ & WES & 6890 & 0.631 & 0.483 & 0 & 1 \\
\hline Process innovation & WES & 8309 & 0.110 & 0.313 & 0 & 1 \\
\hline Patents innovation & WES & 6898 & 0.595 & 0.491 & 0 & 1 \\
\hline GDP (\$US in millions) & WDI & 23 & 160000 & 261000 & 4,720 & $1,080,000$ \\
\hline GDP pc (\$US) & WDI & 23 & 4766 & 3907 & 435 & 12,344 \\
\hline Population (Millions) & WDI & 23 & 35.300 & 52.800 & 1.96 & 239 \\
\hline School Enrollment Net (\%) & WDI & 20 & 61.500 & 16.300 & 27.8 & 83.9 \\
\hline School Enrollment Gross & WDI & 23 & 70.100 & 21.000 & 24.6 & 93.2 \\
\hline
\end{tabular}

\footnotetext{
${ }^{2}$ None of the firms have the three kinds of innovative aspects in the company.
} 


\begin{tabular}{|l|c|c|c|c|c|c|}
$(\mathbf{\%})$ & & & & & & \\
\hline Time Spent in Regulations & WES & 14700 & 13.566 & 19.297 & 0 & 100 \\
\hline Financial development 1 & WDI & 11774 & 24.932 & 21.253 & 2.267 & 93.161 \\
\hline Financial development 2 & WDI & 11774 & 21.881 & 17.582 & 2.267 & 93.161 \\
\hline English & $\begin{array}{c}\text { The Foreign Low } \\
\text { Guide }\end{array}$ & 15215 & 0.064 & 0.245 & 0 & 1 \\
\hline French & $\begin{array}{c}\text { The Foreign Low } \\
\text { Guide }\end{array}$ & 15215 & 0.923 & 0.267 & 0 & 1 \\
\hline Scandinavian & $\begin{array}{c}\text { The Foreign Low } \\
\text { Guide }\end{array}$ & 15215 & 0.013 & 0.114 & 0 & 1 \\
\hline
\end{tabular}

Regarding our macro variables, the richest country in the sample in terms of GDP is Mexico, with an average gross domestic product of $\$ 1.084$ billion between 2006 and 2013, while the poorest is Gambia with an average GDP of $\$ 874$ million in the same time frame, which provides significant variation. Alternatively, the largest country in terms of population is Indonesia (239,000,000 people on average between 2006 and 2013), and the smallest is Botswana $(1,959,708$ people). It is important to consider the country size because larger countries with more people have larger economies.

To estimate the effects of financial development on innovation, we use two different measures for financial development. As we explained before and as was suggested by Levine et al. (2000), Levine (2005), Beck et al. (2007), , and others, the main measure we use is the ratio of private credit to GDP. There is a significant difference in the ratio across countries in the sample, ranging from a low of $2 \%$ to a high of $93 \%$. An alternative measure of a country's financial development is the ratio of private credit by deposit money banks to GDP. As we are conscious that this proxy does not include credit to the private sector by non-deposit money banks, this measure is better viewed as a robustness check. The data of the instrumental variable and legal origins comes from The Foreign Law Guide (Marci Hoffman, 2014). Of the countries in the sample, 92\% have French legal origins, 7\% have English legal origins, and 1\% have Scandinavian legal origins.

\section{IV.Empirical Specification}

Given that our dependent variable is a dummy that equals 1 when the innovation index is greater than 0 and equals 0 when the innovation index is 0 , we initially employ a probit model to estimate the effects of financial development on the probability of a firm to innovate. The empirical model is as follows:

$$
\begin{aligned}
& \left\{1_{\text {InnDummy }_{i}>0}\right\}=\operatorname{Pr}\left(\alpha+\delta_{j y}+\beta_{0} \text { Size }_{i j c}+\beta_{1} \text { Findev }_{1 c}+\beta_{2} \text { Findev }_{1_{c}} * \text { Size }_{i j c}+\right. \\
& \beta_{3} \text { GDPPC }_{c}+\beta_{4} G D P P C_{c} * \text { Size }_{i j c}+\beta_{5} \text { Sennet }_{c}+\beta_{6} \text { Sennet }_{c} * \text { Size }_{i j c}+ \\
& \left.\beta_{7} \text { TimeSpentReg }_{i j c}+\beta_{8} \text { TimeSpentReg }_{i j c} * \text { Size }_{i j c}+\varepsilon_{i j c} \geq 0\right)
\end{aligned}
$$


Where Inndummy is the probability of a firm to innovate, $\delta_{j y}$ are industry and year dummies to control for cross industry heterogeneity and potential yearly variation, Size $_{i j c}$ is the firm size based on the number of employees, Findev $1_{1}$ is the financial development of a country, Findev $_{1_{c}} *$ Size $_{i j c}$ is the relationship between the financial development of a country and the firm size, $G D P P C_{c}$ is the size of the economy of a country, $G D P P C_{c} * S i z e_{i j c}$ is the relationship

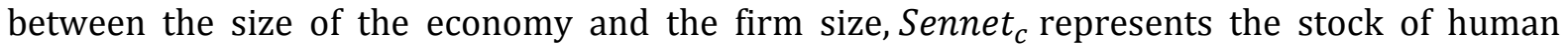
capital of a country, Sennet $_{c} *$ Size $_{i j c}$ is the relationship between the human capital and the firm size, TimeSpentReg ${ }_{i j c}$ represents the institutional environment in which the firm operates, and TimeSpentReg $g_{i j c} * S_{i z e} e_{i j c}$ is the relationship between the institutional environment and the firm size.

As there is an endogenous relationship between financial development and innovation, we correct the model estimating a two-step probit using legal origins as an instrumental variable. We use two-step estimation instead of maximum likelihood because the latter requires a specific complete set of instruments and, consequently, usually becomes inconsistent if any instrument is omitted, while the two-step estimation could sacrifice efficiency but not consistency in the same conditions. In the first stage, we estimate financial development as a function of legal origins (English, French, Scandinavian, or German), and in the second stage, we use the estimated financial development to estimate the probability of a firm to innovate.

As the main purpose of this paper is to identify the effects financial development has on the probability to innovate, the first explanatory variable we consider in the model is financial development. If positive, the coefficient of this variable would indicate that more financially developed countries have greater probability to innovate. If negative, it would indicate that more financially developed countries have lower probability to innovate. Existing literature (Benfratello et al., 2008; Dabla-Norris et al., 2012), finds a positive link between those variables, but as we are considering only developing countries, the effects are not yet clear. We also consider the interaction between financial development and firm size in order to determine if financial development has different effects on firms, depending on their size. A positive $\beta_{2}$ would signify that financial development increases the probability to innovate to a larger extent in large firms. In contrast, a negative $\beta_{2}$ would indicate that financial development boosts the probability to innovate to a larger extent in small firms. Also, the firm size is an independent variable in the model.

Likewise, the income level of a country is considered in the model as a control for the size of the economy. In this case, a positive $\beta_{3}$ would imply that if a firm operates in a larger economy, its probability to innovate is also greater, but a negative coefficient implies that larger economies have lower probability to innovate. We expect this relationship to be positive 
because when there are more resources in a country, there is greater investment in research and development and, consequently, greater probability to innovate. As done with financial development, we interact the GDP per capita with the firm size. We do this to evaluate how the size of the economy affects firms differently. Consequently, the interpretation of the coefficient is similar to the interpretation of the interaction between financial development and firm size. A positive coefficient would indicate that a larger economy increases the probability to innovate to a greater extent in large firms, while a negative coefficient would signify that a larger economy improves the probability to innovate to a greater extent in small firms.

As used by Levine and Renelt (1992), Barro (1991), and Mankiw et al. (1992), we use net school enrollment as a proxy for human capital. A positive $\beta_{5}$ for this variable would indicate a positive relationship between human capital and the probability to innovate. Consequently, a larger supply of human capital in a country increases the probability to innovate. In contrast, a negative $\beta_{5}$ would indicate a negative relationship between the variables. It is important to consider human capital as a control because when there are higher levels of education among the population, there is more knowledge that could be employed to develop new products, services, processes, or patents. That is why we expect a positive coefficient for this variable.

In order to examine ways the effect changes between firms based on size, we cross human capital with firm size. A positive coefficient of this variable would imply that a larger stock of human capital in a country would benefit large firms to a greater degree, while a negative coefficient would indicate the contrary. In this case, we expect a negative coefficient for $\beta_{6}$ because if the stock of human capital is larger, the smaller firms increase their probability to have skilled employees.

As explained by Camagni (1995) and Moguillansky (2006), variables related to the environments where firms operate are also important factors that facilitate innovation. That is why the last explanatory variable we consider is the percentage of senior management time spent dealing with government regulations. A positive coefficient for this variable would imply that if more time is needed to deal with government regulations, the probability to innovate would increase. A negative coefficient signifies that less time needed to deal with government regulations would lead to an increase in the probability to innovate. For this institutional variable, we expect a negative $\beta_{7}$. If the conditions in which a firm operates makes it harder to innovate, it is reasonable to suppose that the probability to innovate would decrease. As we did with all the independent variables, we crossed this indicator with the firm size. If the coefficient of this interaction is positive, it implies that the institutional variable benefits the larger firms more. 
Finally, we also use industry dummies to explain how operating in a specific sector could boost or lower the probability to innovate.

\section{Results and Discussion}

Table 2 presents the results obtained from the first specification of the model and shows the estimated coefficients and their p-values in parentheses. The probability to innovate is the dependent variable on the first column of the table. In this first analysis, considering that endogeneity was not corrected, the results of the financial development are not very consistent but are always statistically significant. When just financial development and firm size based on number of employees are taken into account, the sign of financial development is negative, and the firm size has a positive sign, which intuitively means the whole effect of financial development is negative to the probability to innovate, and the effect of the firm size augments the probability to innovate. However, this result is not conclusive due to the lack of other important variables. When other variables are included, the effect of financial development seems to be different. For example, when financial development, firm size, and GDP per capita are considered, the total effect of financial development appears to be positive, as suggested by Sharma (2007), but the sign of GDP per capita does not make sense according to economic theory (Schumpeter, 1911; King and Levine, 1993; Levine et al., 2000). That is why measures of human capital (Marvel and Lumpkin, 2007) and an institutional environment variable that considers the relationship between enterprise and government (Sylla et al.,2006) are introduced in the first stage and subsequently interacted with firm size. When this happens, the sign of financial development changes again.

The regression that includes all the controls indicates the effect of financial development is negative, meaning an increase in financial development reduces the probability of a firm to innovate in developing countries, but at the same time, this probability increases for large enterprises due to the positive sign of the interaction between size and financial development. This result may explain the variation in financial development's sign among the regressions because the initial specifications were not able to absorb the companies' size effects. This first approach, although inconclusive, is contrary with the literature on the topic. According to Tadesse (2005), a well-developed financial system mobilizes high amounts of capital. What could be happening in these countries is the financial system is not structured, or not as developed as it needs to be to allow capital mobilization over all kinds of enterprises, instead of just the large ones. Because most enterprises are medium or small, the total effect is negative. These results also contradict Benfratello et al.'s (2008) results. Although their study focuses on Italy, it does not differentiate the effect of financial development over the development level of the economies, and that could cover a general effect. 

Table 2 The effect of financial development on the probability to innovate: Probit regressions

\begin{tabular}{|c|c|c|c|c|c|}
\hline Variables & (1) & (2) & (3) & (4) & (5) \\
\hline \multirow[t]{2}{*}{ Financial Development } & $-0.00620^{* * *}$ & $0.00216^{* * *}$ & 0.000327 & 0.000396 & $-0.0123^{* * *}$ \\
\hline & $(0.000594)$ & $(0.000674)$ & $(0.000839)$ & $(0.000855)$ & $(0.00265)$ \\
\hline \multirow[t]{2}{*}{ Size } & $0.137^{* * *}$ & $0.221^{* * *}$ & $0.223^{* * *}$ & $0.222^{* * *}$ & $0.663^{* * *}$ \\
\hline & $(0.0155)$ & $(0.0164)$ & $(0.0188)$ & $(0.0191)$ & $(0.120)$ \\
\hline GDPpc & & $\begin{array}{c}-0.000143^{* * *} \\
(4.12 \mathrm{e}-06)\end{array}$ & $\begin{array}{c}-0.000151^{* * *} \\
(5.50 \mathrm{e}-06)\end{array}$ & $\begin{array}{c}-0.000150^{* * *} \\
(5.57 \mathrm{e}-06)\end{array}$ & $\begin{array}{c}-0.000241^{* * *} \\
(1.39 \mathrm{e}-05)\end{array}$ \\
\hline School Enrollment net & & & $\begin{array}{c}0.00507^{* * *} \\
(0.00170)\end{array}$ & $\begin{array}{c}0.00458^{* * *} \\
(0.00173)\end{array}$ & $\begin{array}{l}0.0280^{* * *} \\
(0.00424)\end{array}$ \\
\hline Time Spent in Regulations & & & & $\begin{array}{c}-0.00106 \\
(0.000731)\end{array}$ & $\begin{array}{c}0.00143 \\
(0.00191)\end{array}$ \\
\hline Financial Development*Size & & & & & $\begin{array}{c}0.00571^{* * *} \\
(0.00117)\end{array}$ \\
\hline GDPpc*Size & & & & & $\begin{array}{c}4.64 \mathrm{e}-05^{* * *} \\
(6.68 \mathrm{e}-06)\end{array}$ \\
\hline School Enrollment net*Size & & & & & $\begin{array}{l}-0.0124^{* * *} \\
(0.00216)\end{array}$ \\
\hline Time Spent in Reg*Size & & & & & $\begin{array}{c}-0.00127 \\
(0.000934)\end{array}$ \\
\hline Sector and Year Dummies & Yes & Yes & Yes & Yes & Yes \\
\hline Observations & 11,768 & 11,768 & 9,371 & 9,101 & 9,101 \\
\hline Pseudo $\mathrm{R}^{2}$ & 0.0667 & 0.1485 & 0.1602 & 0.1629 & 0.1664 \\
\hline Prob $>\mathrm{Chi}^{2}$ & 0.000 & 0.000 & 0.000 & 0.000 & 0.000 \\
\hline $\begin{array}{l}\text { Notes: Standard errors in pa } \\
\text { Significance levels: } * * * \mathrm{p}<0.0 \\
\text { Time Spent in Regulations } \mathrm{m} \\
\text { government regulation" }\end{array}$ & $\begin{array}{l}\text { heses } \\
\text { p }<0.05 \text {, } \\
\text { s "Percer }\end{array}$ & of senior & gem & ent & vith \\
\hline
\end{tabular}

Table 3, on the other hand, presents the results obtained from the second specification of the model, which takes into account the endogenous relationship between financial development and the probability of innovation. In this table it is possible to see the estimated coefficients and their p-values in parentheses. It is important to note that the instrumental variable fixes the endogeneity over financial development (the ratio of private credit to GDP), an action that also indirectly eliminates the endogenous relationship contained in GDP per capita. This happens because the channel through which GDP affects innovation is financial development, and we are measuring this with an exogenous variable. When the model considers the endogenous relationship, the financial development sign is negative for all specifications and statistically significant at the $1 \%$ level, which confirms the explanation above about firm size and capital mobilizations. In other words, in developing countries, financial development reduces the probability of a firm to innovate because it only mobilizes resources for large firms, and the majority of firms are small or medium. This result can also be explained based on Yan et al. (2014), who say that "for an emerging country with insufficient capital, a more developed 
credit market might imply a highly leveraged capital structure that cannot afford losses from risky investment and thus would discourage investments in innovative projects." (Yan et al., 2014). In addition, these authors also suggest that weak legal structures, which could be evidenced by the time managers spend dealing with government issues, are also associated with fewer innovation processes (Yan et al., 2014). Even more, with this result and considering King and Levine's (1993) results, it can be said that if financial development spurs growth, even in developing countries, the channel through which this is done is not innovation. The above is reinforced with the remaining results, which indicate firm size is a positive and is statistically significant at $1 \%$ and the time spent by senior managers dealing with government regulations has a negative effect on innovation and is significant at $5 \%$, but it has a positive effect if the firm is larger (Time Spent In Regulations*Size has a 5\% significance).

Thus, under the circumstances in these countries, the GDP per capita of the economy that has a statistical significance of 5\%, the positive effects over the smaller firms (GDPpc*Size has significance of 5\%), and the accumulation of human capital, which increases the probability to innovate at smaller firms (both with a significance level of 1\%) might work to increase the probability to innovate.

Table 3 the effect of financial development on the probability to innovate: Instrumented Probit Regressions

\begin{tabular}{|c|c|c|c|c|c|}
\hline Variables & (1) & (2) & (3) & (4) & (5) \\
\hline Financial & 0.00239 & $-0.0345^{* *}$ & $-0.401^{* * *}$ & $-0.374^{* * *}$ & $-2.279 * * *$ \\
\hline Development & $(0.00430)$ & $(0.0175)$ & $(0.0942)$ & $(0.0838)$ & $(0.855)$ \\
\hline Size & $0.128^{* * *}$ & $0.214^{* * *}$ & 0.0349 & 0.0408 & $29.71^{* * *}$ \\
\hline size & $(0.0163)$ & $(0.0189)$ & $(0.128)$ & $(0.119)$ & (10.97) \\
\hline & & $-5.50 e-05$ & $0.000271^{* *}$ & $0.000245^{* * *}$ & $0.000911^{* *}$ \\
\hline GDPpc & & $(4.27 e-05)$ & $(0.000106)$ & $(9.48 e-05)$ & $(0.000460)$ \\
\hline School Enrollment & & & $0.301^{* * *}$ & $0.285^{* * *}$ & $1.729^{* * *}$ \\
\hline & & & $(0.0694)$ & $(0.0628)$ & $(0.639)$ \\
\hline Time Spent in & & & & $-0.0163^{* * *}$ & $-0.0690^{* *}$ \\
\hline Regulations & & & & $(0.00546)$ & $(0.0330)$ \\
\hline Financial & & & & & $1.029^{* * *}$ \\
\hline Development*Size & & & & & $(0.386)$ \\
\hline GDPpc*Size & & & & & $\begin{array}{c}-0.000582^{* *} \\
(0.000248)\end{array}$ \\
\hline School Enrollment & & & & & $-0.769^{* * *}$ \\
\hline net*Size & & & & & $(0.285)$ \\
\hline Time Spent in & & & & & $0.0466^{* *}$ \\
\hline Regulations *Size & & & & & $(0.0206)$ \\
\hline & -0.3380603 & 0.6826828 & -13.51751 & -12.5961 & -66.33474 \\
\hline Constant & $(0.1029252)$ & $(.1435329)$ & $(-3.1662)$ & $(-2.83203)$ & $(-24.6051)$ \\
\hline $\begin{array}{l}\text { Sector and Year } \\
\text { Dummies }\end{array}$ & Yes & Yes & Yes & Yes & Yes \\
\hline Observations & 11,768 & 11,768 & 9,371 & 9,101 & 9,101 \\
\hline $\begin{array}{l}\text { Wald test of } \\
\text { exogeneity } \mathrm{Chi}^{2}\end{array}$ & 3.66 & 6.77 & 82.2 & 87.53 & 234.68 \\
\hline
\end{tabular}

Finally, it is important to analyze the marginal effects at the mean to understand the implications of the results. Table 4 shows the marginal effects of each variable in the model at 
the mean in the second column and the standard error, the test statistic $\mathrm{z}$, the $P$ value, and the mean, respectively. Based on these results, for a firm located in Argentina in 2010, a year in which the country was around the mean value of FD, and assuming the other variables were also approximate to the mean, an increase of $1 \%$ in the financial development indicator would have reduced the probability of innovation at such firm by 0.89 percentage points. However, this same increase in financial development would have caused an increase in the probability to innovate of around 0.5 percentage points if the firm is large. This means the probability of innovation at a medium size firm compared to a large size firm is $11.5 \%$ lower, and the probability a small enterprise innovates compared with a large one is $23 \%$ lower.

Moreover, the effects of the control variables over innovation are relevant. If the country increases its school enrollment by $1 \%$, the probability for the average firm in the sample to innovate increases by 0.67 percentage points, and if the firm is small, this increase in human capital leads to an increase in the probability to innovate. Also, if the firm is within the average values, an increase of $1 \%$ of manager's time spent dealing with government regulations leads to a reduction of 0.028 percentage points in the probability of innovation. Because this last marginal effect is very low, one could say the thesis on the need for institutional stability and the prejudice caused by the incumbents, as indicated by Sylla et al. (2006), is true but must be corroborated by other specifications, as done by LeBel (2008).

It is relevant to note that the sector that enhances the probability of a firm to innovate the most is the food sector, taking into consideration that other manufacturing may contain a large variety of economic activities. Meanwhile, a firm in the metal and machinery sector has the lowest probability to innovate. These results are not statistically significant, however.

Finally, the results are robust using an alternative measure of financial development that as described above consists of the private credit only emitted by banks to GDP. Results are similar with estimates of the regression without considering the endogenous relationship and then are also similar to the previous results. It is relevant to consider that the results were not robust with an alternative measure of company size. While using sales of the company the variables were omitted because of co-linearity, which impedes an appropriate analysis of the results. (see Appendix 2) 
Table 4 Marginal effects at the mean for Instrumented Probit Regressions

\begin{tabular}{|c|c|c|c|c|c|c|}
\hline Variable & $\mathrm{dy} / \mathrm{dx}$ & Std. Err. & $\mathbf{z}$ & $P>z$ & $\begin{array}{l}95 \% \\
\text { Conf. }\end{array}$ & Interval \\
\hline Financial Development & -0.899 & 0.100 & -8.950 & 0.000 & -1.096 & -0.702 \\
\hline Financial Development*Size & 0.407 & 0.045 & 8.950 & 0.000 & 0.318 & 0.496 \\
\hline Size & 11.552 & 1.281 & 9.020 & 0.000 & 9.041 & 14.063 \\
\hline GDP pc & 0.000 & 0.000 & 7.490 & 0.000 & 0.000 & 0.000 \\
\hline GDPpc*Size & 0.000 & 0.000 & -8.400 & 0.000 & 0.000 & 0.000 \\
\hline School Enrollment net & 0.671 & 0.075 & 8.970 & 0.000 & 0.524 & 0.818 \\
\hline School Enrollment net*Size & -0.301 & 0.033 & -9.000 & 0.000 & -0.367 & -0.236 \\
\hline Time Spent in regulations & -0.028 & 0.003 & -8.640 & 0.000 & -0.034 & -0.022 \\
\hline Time Spent in Regulations*Size & 0.019 & 0.002 & 8.690 & 0.000 & 0.015 & 0.023 \\
\hline resother & -0.004 & 0.001 & -5.080 & 0.000 & -0.006 & -0.002 \\
\hline Sector: Garments & 0.015 & 0.019 & 0.830 & 0.406 & -0.021 & 0.052 \\
\hline Sector: Food & -0.029 & 0.018 & -1.630 & 0.104 & -0.064 & 0.006 \\
\hline Sector: Metals and machinery & -0.078 & 0.020 & -3.920 & 0.000 & -0.117 & -0.039 \\
\hline Sector: Electronics & 0.105 & 0.029 & 3.560 & 0.000 & 0.047 & 0.163 \\
\hline Sector: Chemicals and pharmaceuticals & 0.076 & 0.019 & 4.080 & 0.000 & 0.039 & 0.112 \\
\hline Sector: Wood and furniture & 0.048 & 0.066 & 0.730 & 0.465 & -0.081 & 0.176 \\
\hline $\begin{array}{l}\text { Sector: Non-metalic and plastic } \\
\text { materials }\end{array}$ & -0.091 & 0.021 & -4.300 & 0.000 & -0.132 & -0.049 \\
\hline Secotor: Auto and auto components & 0.117 & 0.135 & 0.870 & 0.383 & -0.146 & 0.381 \\
\hline Sector: Other manufacturing & -0.116 & 0.020 & -5.810 & 0.000 & -0.155 & -0.077 \\
\hline Sector: Retail and wholesale trade & -0.162 & 0.124 & -1.300 & 0.193 & -0.406 & 0.082 \\
\hline Sector: Other services & -0.128 & 0.115 & -1.110 & 0.267 & -0.354 & 0.098 \\
\hline Year 2009 & -0.461 & 0.018 & -25.800 & 0.000 & -0.496 & -0.426 \\
\hline
\end{tabular}

\section{VI.Conclusions}

The main conclusion of this paper is that financial development has a negative effect on the probability of a firm to innovate in developing countries. This conclusion is based on three reasons. According to Tadesse $(2005,2006)$, financial development affects innovations in terms of capital mobilization, which means more financially developed countries have greater amounts of capital flowing through their economies. However, the amount of capital in the economy is not necessarily well distributed between all firms. The conclusion is the financial system in these countries is structured in a way that only facilitates innovation at the largest firms. This can also be affirmed based on Yan et al. (2014), who concluded that in developing countries, the amount of private credit due to insufficient capital increases risk and, 
consequently, discourages investments in innovations. In addition, according to Sylla et al. (2006), incumbents only support financial development if it represents an explicit gain for them. Otherwise, they interfere in the political system to stop any project that could diminish their privileged positions. Based on our results, only large firms benefit from the amount of time senior management spends dealing with government regulations, which may imply lobbyrelated activites (Time Spent in Regulations variable). These firms are the ones who increase their probability to innovate. Although restricted by the magnitude of the estimators, this result is a confirmation of these authors' theses. Finally, although we found different signs compared to those obtained by Sharma (2007), the firm size matters when it comes to the effect of financial development on the probability to innovate. Because most companies in these countries are small or medium size, the negative effect of the financial development is more relevant than the positive effect it represents for large firms. It could also be concluded, according to King and Levine (1993), that the channel through which financial development spurs growth in developing countries is not innovation because the capital does not reach the smallest firms. In summary, the negative effect of financial development on the probability of a firm to innovate corresponds, according to literature, to the design of the financial system, the lack of capital, and the influence incumbents may have on the design of the system, with the results benefiting large firms. 


\section{References}

Barro, Robert J, "Economic Growth in a Cross Section of Countries," The Quarterly Journal of Economics 106 (1991):407-443.

Beck ,Thorsten, and Ross Levine, "Industry Growth And Capital Allocation: Does Having A Market- Or Bank-Based System Matter?" Journal of Financial Economics 64 (2002):147-180.

Beck, Thorsten, Asli Demirgüç-Kunt, and Ross Levine, "Finance, inequality and the poor," Journal of Economic Growth 12 (2007):27-49.

Benfratello, Luigi, Fabio Schiantarelli, and Alessandro Sembenelli, "Banks and Innovation: Microeconometric Evidence on Italian Firms." Journal of Financial Economics 90 (2008):197217.

Bhattacharya, Mita, and Harry Bloch, H., "Determinants of innovation." Small Business Economics 22 (2004):155-162.

Blanco, Luisa, "Finance, growth and institutions in Latin America: What are the links?." Journal of Economics 50 (2013):179-208.

Brown, James, Martinsson Gustav, and Peters Bruce, "Do Financing Constraints Matter for R\&D? New Tests and Evidence." European Economic Review 56 (2012):1512-1529.

Camagni, Roberto, "The Concept of Innovative Milieu and its Relevance for Public Policies in European Lagging Regions." Papers in Regional Science 74 (1995):317-340.

Clarke, George, Lixin Colin Xu, and Heng-Fu Zou, "Finance and Income Inequality: What Do the Data Tell Us?" Southern Economic Journal 72 (2006):578-596.

Dabla-Norris Era, Erasmus Kersting, and Geneviéve Verdier, "Firm Productivity, Innovation, and Financial Development." Southern Economic Journal Volume 79 (2012):422-449.

King, Robert, and Ross Levine, "Schumpeter Might be Right." The Quarterly Journal of Economics 108 (1993):717-737.

La Porta, Rafael, Folrencio Lopez-de-Silanes, Andrei Shleifer, and Robert Vishny, "Legal Determinants of External Finance." Journal of Finance 52 (1997):1131-1150.

"Law and Finance." Journal of Political Economy 106 (1998):1113-1155.

LeBel, Phillip, "The role of creative innovation in economic growth: Some international comparisons." Journal of Asian Economics 19 (2008):334-347.

Levine Ross, "Financial development and Economic Growth: Views and Agenda." Journal of Economic Literature 35 (1997):688-726.

, "Finance and Growth: Theory and Evidence" in Philippe Aghion, and Steven Durlauf (ed.) Handbook of Economic Growth 1 (2005): 865-934.

Levine, Ross, and David Renelt, "A Sensitivity Analysis of Cross-Country Growth Regressions." The American Economic Review 82 (1992): 942-963.

Levine, Ross, Norman Loayza, and Thorsten Beck, "Financial intermediation and growth: Causality and causes." Journal of Monetary Economics 46 (2000):31-77.

Mankiw, Gregory, David Romer, and David Weil, "A Contribution to the Empirics of Economic Growth." The Quarterly Journal of Economics 107 (1992):407-437.

Marci ,Hoffman, "Foreign Law Guide." BrillOnline Reference Works Available at http://referenceworks.brillonline.com/browse/foreign-law-guide (2014).

Marvel , Matthew and G.T Lumpkin, "Technology Entrepreneurs' Human Capital and Its Effects on Innovation Radicalness." Entrepreneurship Theory and Practice Volume 31 (2007):807-828.

Moguillansky, Graciela, "Innovation, the Missing Link in Latin American Countries." Journal of Economic Issues 15 (2006):342-357.

Rajan, Raghuram, and Luigi Zingales, "Financial Dependence and Growth." American Economic Review 88 (1998):559-586.

Rousseau, Peter, and Paul Wachtel, "What is happening to the impact of financial deepening on economic growth?." Economic Inquiry 49 (2011): 276-288. 
Schumpeter, Joseph,. "The Theory of Economic Development: An Inquiry into Profits, Capital, Credit, Interest, and the Business Cycle." Ed. 2011, Kindle Edition (1911)

Sharma, Siddharth, "Financial Development and Innovation in Small Firms." Policy Research Working Papers (2007):1-33.

Sylla, Richard, Raghuram Rajan, and Luigi Zingales, "Schumpeter Redux: A Review of Raghuram G. Rajan and Luigi Zingales's "Saving Capitalismfrom the Capitalists." Journal of Economic Literature 44 (2006):391-404.

Tadesse, Solomon, "Financial Development and Technology" William Davidson Institute Working Paper 749 (2005).

"Innovations, information and financial architecture." Journal of financial and quantitive analysis 41 (2006):753-786.

The World Bank, The World Bank: Data. Available at http://data.worldbank.org/ (2013).

World Bank Group, Enterprise Surveys. Available at http://www.enterprisesurveys.org/ (2013). Yan, Xu, Po-Hsuan Hsu, and Xuan Tian, "Financial development and innovation: Cross-country evidence." Journal of Financial Economics Volume 112 (2014):116-135. 


\section{Appendix 1}

Graph 1 Percentage of observations per country

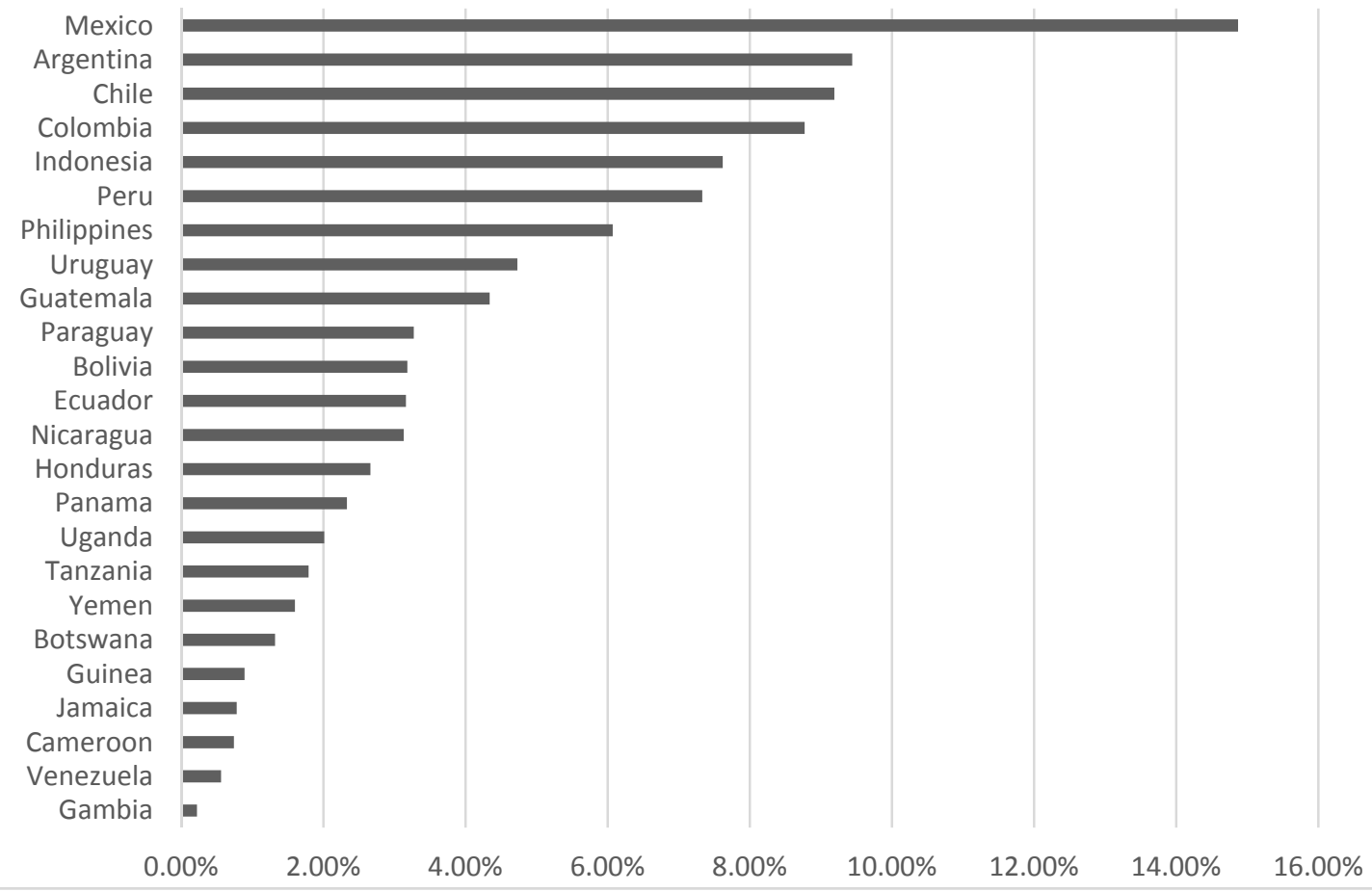

Source: Table processed with data obtained from World Enterprise Surveys

Graph 2 Sectors on the sample

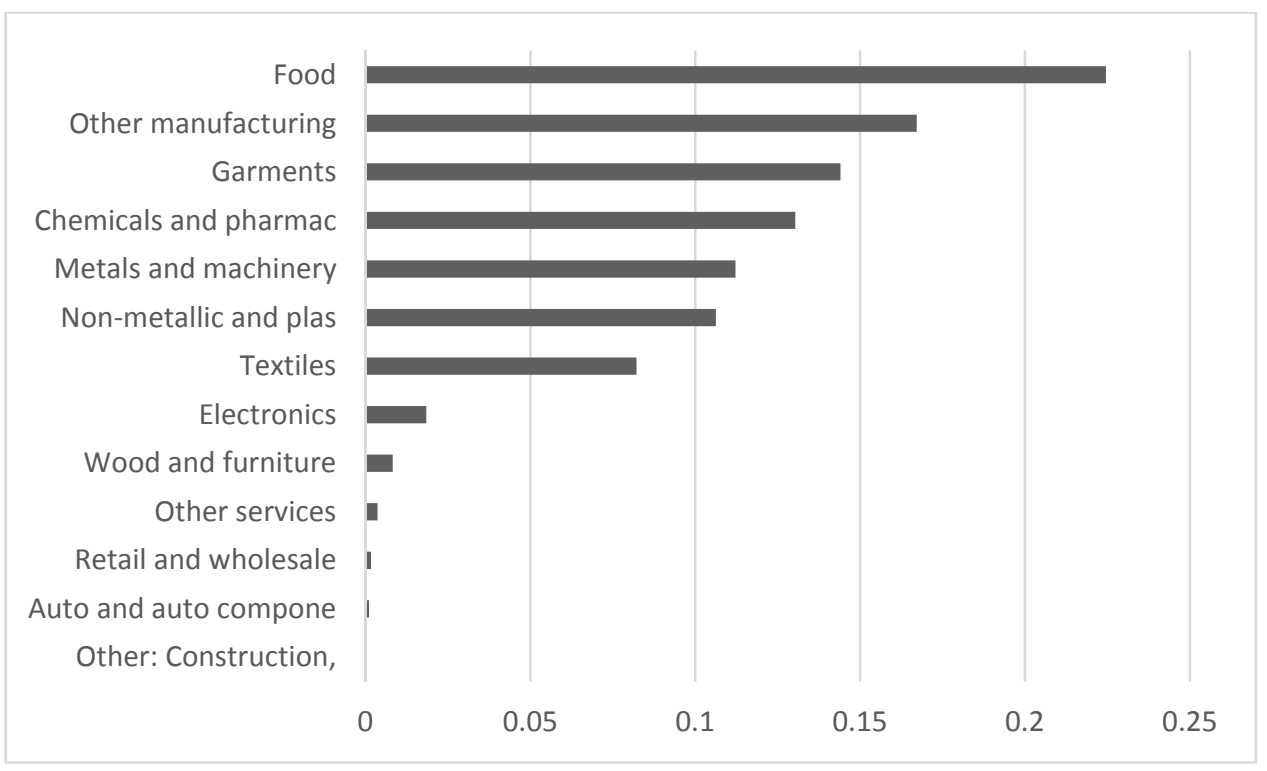

Source: Graphic processed with data obtained from the World Bank Database 


\section{Appendix 2}

Table 5 the effect of financial development on the probability to innovate: Probit Regressions, Robustness check

\begin{tabular}{|c|c|c|c|c|c|}
\hline Variables & (1) & (2) & (3) & (4) & (5) \\
\hline Financial Development2 & $\begin{array}{c}-0.00327^{* * *} \\
(0.000689)\end{array}$ & $\begin{array}{l}0.00478 * * * \\
(0.000761)\end{array}$ & $\begin{array}{l}0.00292^{* * *} \\
(0.000958)\end{array}$ & $\begin{array}{l}0.00318^{* * *} \\
(0.000979)\end{array}$ & $\begin{array}{c}-0.00646^{* *} \\
(0.00281)\end{array}$ \\
\hline Size & $\begin{array}{l}0.131^{* * *} \\
(0.0155)\end{array}$ & $\begin{array}{l}0.223^{* * *} \\
(0.0164)\end{array}$ & $\begin{array}{l}0.224^{* * *} \\
(0.0188)\end{array}$ & $\begin{array}{l}0.224^{* * *} \\
(0.0191)\end{array}$ & $\begin{array}{c}0.581^{* * *} \\
(0.118)\end{array}$ \\
\hline GDPpc & & $\begin{array}{c}-0.000146^{* * *} \\
(4.02 \mathrm{e}-06)\end{array}$ & $\begin{array}{c}-0.000153^{* * *} \\
(5.50 \mathrm{e}-06)\end{array}$ & $\begin{array}{c}-0.000152^{* * *} \\
(5.57 \mathrm{e}-06)\end{array}$ & $\begin{array}{c}-0.000237^{* * *} \\
(1.38 \mathrm{e}-05)\end{array}$ \\
\hline School Enrollment net & & & $\begin{array}{l}0.00417^{* *} \\
(0.00167)\end{array}$ & $\begin{array}{l}0.00360^{* *} \\
(0.00169)\end{array}$ & $\begin{array}{l}0.0229 * * * \\
(0.00411)\end{array}$ \\
\hline Time Spent in Regulations & & & & $\begin{array}{c}-0.00107 \\
(0.000731)\end{array}$ & $\begin{array}{c}0.00141 \\
(0.00190)\end{array}$ \\
\hline Financial Development1*Size & & & & & $\begin{array}{c}0.00442^{* * *} \\
(0.00131)\end{array}$ \\
\hline GDPpc*Size & & & & & $\begin{array}{c}4.42 \mathrm{e}-05^{* * *} \\
(6.69 \mathrm{e}-06)\end{array}$ \\
\hline School Enrollment net*Size & & & & & $\begin{array}{l}-0.0104^{* * *} \\
(0.00211)\end{array}$ \\
\hline Time Spent in Regulations*Size & & & & & $\begin{array}{c}-0.00128 \\
(0.0009323)\end{array}$ \\
\hline Constant & $\begin{array}{c}-0.222 * * * \\
(0.0515)\end{array}$ & $\begin{array}{l}0.376^{* * *} \\
(0.0560)\end{array}$ & $\begin{array}{l}-0.0783 \\
(0.108)\end{array}$ & $\begin{array}{l}-0.0226 \\
(0.111)\end{array}$ & $\begin{array}{c}-0.648^{* * *} \\
(0.230)\end{array}$ \\
\hline Sector and Year Dummies & Yes & Yes & Yes & Yes & Yes \\
\hline Observations & 11,768 & 11,768 & 9,371 & 9,101 & 9,101 \\
\hline Pseudo $\mathrm{R}^{2}$ & 0.061 & 0.1503 & 0.1609 & 0.1604 & 0.1657 \\
\hline Prob $>\mathrm{Chi}^{2}$ & 0.000 & 0.000 & 0.000 & 0.000 & 0.000 \\
\hline $\begin{array}{l}\text { Notes: Standard errors in pare } \\
\text { Significance levels: }{ }^{* * *} p<0.01 \text {, } \\
\text { Time Spent in Regulations mea } \\
\text { government regulation" }\end{array}$ & $\begin{array}{l}\text { ses } \\
<0.05, * \\
\text { Percenta }\end{array}$ & enior's m & sement tin & ent in de & ith \\
\hline
\end{tabular}


Table 6 The effect of financial development on the probability to innovate: Instrumented Probit Regressions, Robustness check

\begin{tabular}{|c|c|c|c|c|c|}
\hline Variables & (1) & (2) & (3) & (4) & (5) \\
\hline Financial Development2 & $\begin{array}{c}0.00239 \\
(0.00430)\end{array}$ & $\begin{array}{c}-0.0345^{* *} \\
(0.0175)\end{array}$ & $\begin{array}{c}-0.401^{* * *} \\
(0.0942)\end{array}$ & $\begin{array}{c}-0.374^{* * *} \\
(0.0838)\end{array}$ & $\begin{array}{c}-0.499^{* * *} \\
(0.0686)\end{array}$ \\
\hline Size & $\begin{array}{l}0.128^{* * *} \\
(0.0163)\end{array}$ & $\begin{array}{l}0.214^{* * *} \\
(0.0189)\end{array}$ & $\begin{array}{l}0.0349 \\
(0.128)\end{array}$ & $\begin{array}{l}0.0408 \\
(0.119)\end{array}$ & $\begin{array}{c}1.557^{* * *} \\
(0.431)\end{array}$ \\
\hline GDPpc & & $\begin{array}{c}-5.50 \mathrm{e}-05 \\
(4.27 \mathrm{e}-05)\end{array}$ & $\begin{array}{l}0.000271^{* *} \\
(0.000106)\end{array}$ & $\begin{array}{c}0.000245^{* * *} \\
(9.48 \mathrm{e}-05)\end{array}$ & $\begin{array}{c}0.000155^{* *} \\
(7.17 \mathrm{e}-05)\end{array}$ \\
\hline School Enrollment net & & & $\begin{array}{l}0.301^{* * *} \\
(0.0694)\end{array}$ & $\begin{array}{l}0.285^{* * *} \\
(0.0628)\end{array}$ & $\begin{array}{l}0.328^{* * *} \\
(0.0448)\end{array}$ \\
\hline Time Spent in Regulations & & & & $\begin{array}{c}-0.0163^{* * *} \\
(0.00546)\end{array}$ & $\begin{array}{l}-0.0140^{* *} \\
(0.00636)\end{array}$ \\
\hline Financial Development1*Size & & & & & $\begin{array}{l}0.272^{* * *} \\
(0.0374)\end{array}$ \\
\hline GDPpc*Size & & & & & $\begin{array}{c}-0.000152^{* * *} \\
(3.54 \mathrm{e}-05)\end{array}$ \\
\hline School Enrollment net*Size & & & & & $\begin{array}{c}-0.0889^{* * *} \\
(0.0132)\end{array}$ \\
\hline Time Spent in Regulations *Size & & & & & $\begin{array}{c}0.00363 \\
(0.00308)\end{array}$ \\
\hline Constant & $\begin{array}{c}-0.338^{* * *} \\
(0.103)\end{array}$ & $\begin{array}{c}0.683^{* * *} \\
(0.144)\end{array}$ & $\begin{array}{c}-13.52^{* * *} \\
(3.166)\end{array}$ & $\begin{array}{c}-12.60^{* * *} \\
(2.832)\end{array}$ & $\begin{array}{c}-11.76^{* * *} \\
(1.757)\end{array}$ \\
\hline \multicolumn{6}{|l|}{ Sector and Year Dummies } \\
\hline Observations & $\begin{array}{c}\text { Yes } \\
11,768\end{array}$ & $\begin{array}{c}\text { Yes } \\
11,768\end{array}$ & $\begin{array}{c}\text { Yes } \\
9,371\end{array}$ & $\begin{array}{c}\text { Yes } \\
9,101\end{array}$ & $\begin{array}{c}\text { Yes } \\
9,101\end{array}$ \\
\hline Wald test of exogeneity $\mathrm{Chi}^{2}$ & 3.66 & 6.77 & 82.2 & 87.53 & 88.55 \\
\hline $\begin{array}{l}\text { Notes: Standard errors in parent } \\
\text { Significance levels: }{ }^{* * *} \mathrm{p}<0.01,{ }^{* *} \\
\text { Time Spent in Regulations mean } \\
\text { government regulation" }\end{array}$ & $\begin{array}{l}.05, * \mathrm{p}< \\
\text { ercentag }\end{array}$ & enior's & gemen & pent in & with \\
\hline
\end{tabular}

